\title{
COVID-19 and Fulminant Clostridium difficile Colitis Co-Infection
}

\author{
Abdul Ahad Ehsan Sheikh¹, Abu Baker Sheikh² ${ }^{2}$ Ishan Shah², Ali Hamza Khair ${ }^{3}$, Nismat Javed ${ }^{3}$, Rahul Shekhar ${ }^{4}$ \\ ${ }^{1}$ The Wright Center for Graduate Medical Education, Department of Internal Medicine, Scranton, PA, USA \\ ${ }^{2}$ University of New Mexico Health Sciences Center, Department of Internal Medicine, Albuquerque, NM, USA \\ ${ }^{3}$ Shifa College of Medicine, Shifa Tameer-e-Millat University, Islamabad, Pakistan
}

${ }^{4}$ Division of Hospital Medicine, University of New Mexico School of Medicine, Department of Internal Medicine, Albuquerque, NM, USA

\section{Doi: 10.12890/2021_002771 - European Journal of Case Reports in Internal Medicine - ๑) EFIM 2021}

Received: $12 / 07 / 2021$

Accepted: $17 / 07 / 2021$

Published: $24 / 08 / 2021$

How to cite this article: Sheikh AAE, Sheikh AB, Shah I, Khair AH, Javed N, Shekhar R. COVID-19 and fulminant Clostridium difficile colitis co-infection. EJCRIM 2021;8: doi:10.12890/2021_002771.

Conflicts of Interests: The authors declare there are no competing interests.

This article is licensed under a Commons Attribution Non-Commercial 4.0 License

\section{ABSTRACT}

The development of Clostridium difficile infection in COVID-19 patients is an understudied complication of the disease. Herein, we present the case of a 46-year-old man who developed severe healthcare-associated $C$. difficile infection leading to toxic megacolon and perforation in the setting of COVID-19 infection. It is important to continue to follow guidelines regarding antibiotics in healthcare settings to prevent such complications.

\section{LEARNING POINTS}

- Co-infection with Clostridium difficile and COVID-19 leads to poor outcomes with high mortality.

- C. difficile infection should be ruled out in COVID-19 patients who develop diarrhoea on antibiotic therapy.

- We should continue to follow the established guidelines of antimicrobial stewardship and remain vigilant for unexpected adverse effects.

\section{KEYWORDS}

COVID-19, antibiotics, microbial resistance, Clostridium difficile

\section{INTRODUCTION}

As infection control measures have increased, we have seen a reduction in hospital-acquired infections including healthcare-associated Clostridium difficile infection (HA-CDI). Although COVID-19 and C. difficile infection (CDI) are rarely reported together, the association has been linked to severe complications ${ }^{[1]}$. Diarrhoea is one of the most common non-pulmonary presenting symptoms seen with COVID-19 ${ }^{[2]}$ This can act as a confounding factor and delay diagnosis and treatment of CDI leading to the worst outcomes.

\section{CASE DESCRIPTION}

A 46-year-old-man with a medical history of obstructive sleep apnoea presented to an outside hospital with shortness of breath and diarrhoea. He subsequently had a positive RT-PCR nasopharyngeal swab test and was diagnosed with COVID-19 pneumonia. Remdesivir, convalescent plasma and methylprednisolone were commenced. Given the high leucocytosis $\left(13.7 \times 10^{3} / \mu \mathrm{l}\right)$ and elevated procalcitonin $(3.2$ $\mathrm{ng} / \mathrm{ml}$ ), the patient was started on intravenous (IV) vancomycin and piperacillin/tazobactam for empiric coverage for bacterial pneumonia. On day 5 , he was intubated for acute hypoxic respiratory failure on the mechanical ventilator and was transferred to our facility for a higher level of care. 
On presentation, his blood pressure was $92 / 55 \mathrm{mmHg}$, heart rate was 63 beats/minute and temperature was $37.3^{\circ} \mathrm{C}$. He had an elevated white cell count $\left(19.8 \times 10^{3} / \mu \mathrm{l}\right)$, creatinine of $0.7 \mathrm{mg} / \mathrm{dl}$ and normal liver function tests. Blood culture from the outside hospital showed no growth and antibiotics were discontinued. A computed tomography (CT) angiogram of chest was negative for pulmonary embolism. Steroids were continued.

On day 7, the patient's feeding tube was dislodged leading to an aspiration event. This resulted in septic shock requiring vasopressors and he was restarted on IV piperacillin/tazobactam. In the next 48 hours, acute elevation in the white cell count from $15.4 \times 10^{3} / \mu$ l to $32 \times 10^{3} /$ $\mu \mathrm{l}$ was noted. Lactic acid increased to $4.2 \mathrm{mmol} / \mathrm{l}$. The patient became oliguric and creatinine rose to $3.21 \mathrm{mg} / \mathrm{dl}$ requiring continuous renal replacement therapy. He was noted to have profuse diarrhoea and a C. difficile PCR test was positive. For further work-up, a CT scan of the abdomen and pelvis was done which showed evidence of pancolitis (Fig. 1). Oral vancomycin with IV metronidazole was initiated and piperacillin/tazobactam was discontinued.

On day 11, the patient's vasopressor requirement abruptly increased. His leucocytosis increased to $57.4 \times 10^{3} / \mu \mathrm{l}$, and his lactate was 6.0 $\mathrm{mmol} / \mathrm{l}$, suggesting the development of toxic megacolon. He underwent an emergency exploratory laparotomy and total abdominal colectomy, performed at the bedside due to COVID-19 precautions. His abdomen was closed following repeat exploratory laparotomy and end ileostomy 2 days later. Overnight, his clinical status acutely worsened with deteriorating metabolic acidosis. He became hypothermic to $35.1^{\circ} \mathrm{C}$, his lactate increased to $12.5 \mathrm{mmol} / \mathrm{l}$, arterial $\mathrm{pH}$ decreased to 7.15 , and haemoglobin decreased to $6.4 \mathrm{~g} / \mathrm{dl}$, requiring the transfusion of 4 units of red blood cells. CT of the abdomen/pelvis revealed haemoperitoneum (Fig. 2). The patient underwent four additional surgeries for the management of persistent haemorrhagic shock, which was further complicated with disseminated intravascular coagulation requiring further resuscitation with blood products.

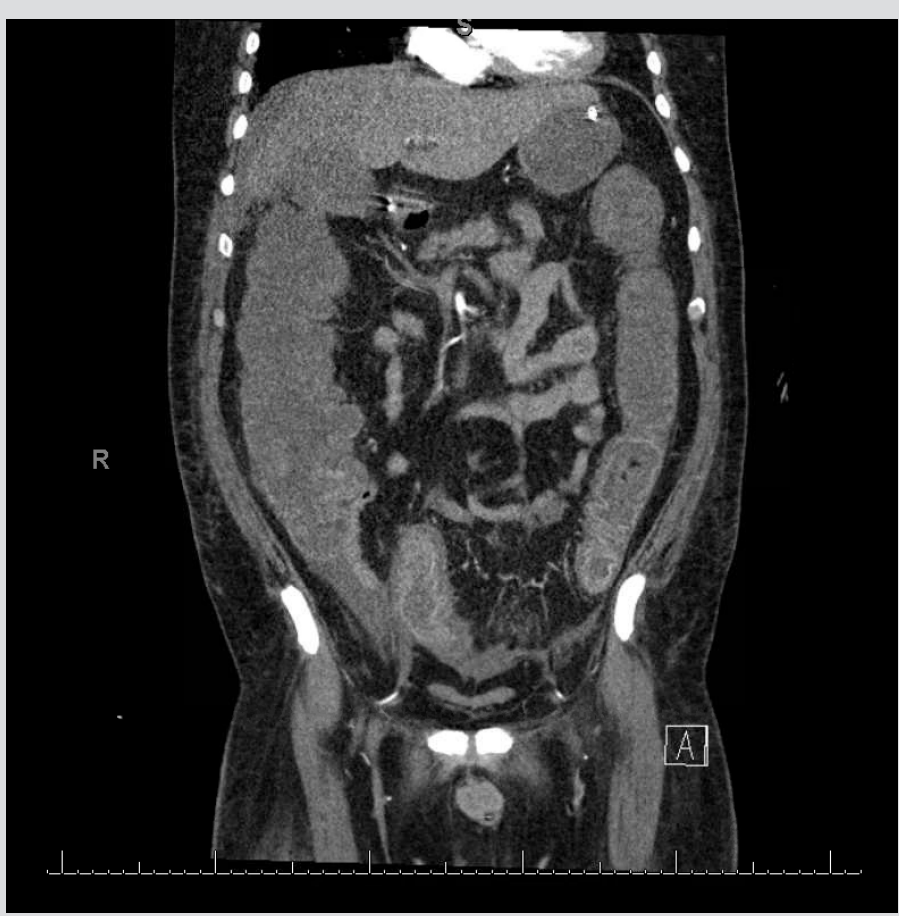

Figure 1. Computed tomography scan showing diffuse mural thickening and oedema of the colon, especially involving the rectum and sigmoid colon consistent with pancolitis

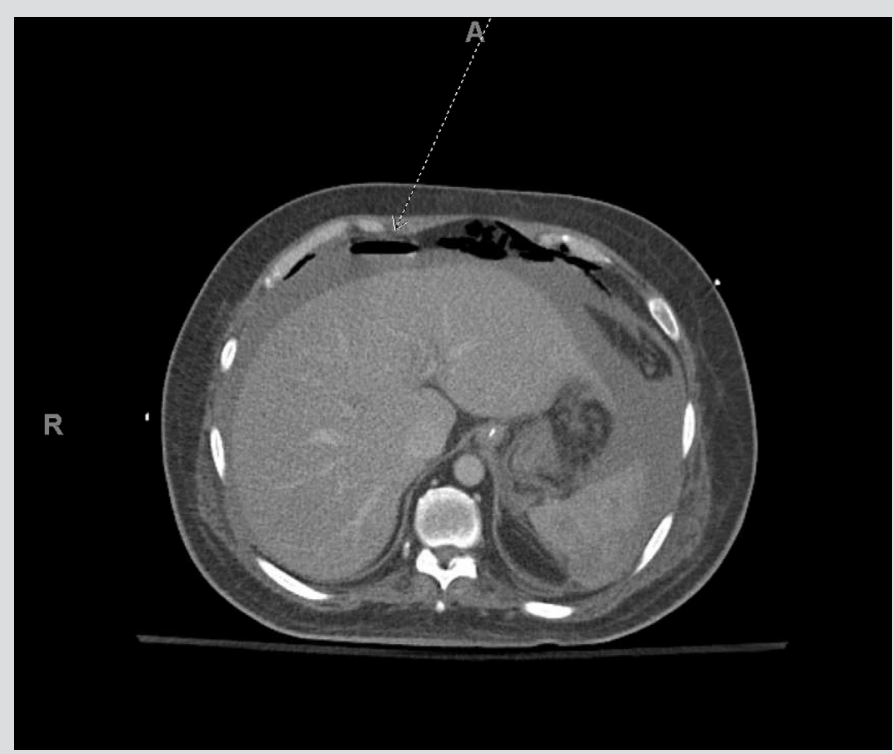

Figure 2. Computed tomography scan of the abdomen and pelvis showing large volume haemoperitoneum (broken arrow)

On hospital day 17, the patient was noted to have ST segment elevations on the monitor. A formal electrocardiogram and serial troponins confirmed the diagnosis of anterior-inferior wall ST elevation myocardial infarction. After discussion with his family, the patient was ultimately transitioned to comfort care and died a few hours later.

\section{DISCUSSION}

Diarrhoea is one of the most common non-pulmonary presenting symptoms of COVID-19, being reported in up to $19 \%$ of patients ${ }^{[2]}$. Patients in the intensive care unit (ICU) have a higher incidence of gastrointestinal dysfunction, especially diarrhoea, due to both infective 
and non-infective causes ${ }^{[3]}$. These factors make diarrhoea a common symptom in mild, moderate and severe COVID-19 disease, which can act as a confounding factor leading to a delay in the diagnosis of CDI.

The COVID-19 pandemic has placed global emphasis on infection prevention measures. Techniques including but not limited to hand hygiene, surface disinfection, social distancing and the adoption of personal protective equipment have all seen an unprecedented rise over the last year, which in turn has resulted in a declining rate of HA-CDI ${ }^{[4]}$.

The use of antibiotics due to anchoring bias remains prevalent in the management of COVID-19 patients worldwide. Rawson et al. reported that $72 \%$ of hospitalized COVID-19 patients received antimicrobial therapy even though only $8 \%$ were reported to have a superimposed bacterial/fungal co-infection ${ }^{[5]}$. Additionally, COVID-19 has the potential to significantly alter the gut microbiota of patients during hospitalization ${ }^{[6]}$. This places patients infected with COVID-19 with an altered gut microbiome at high risk of various antibiotic-associated adverse effects including $\mathrm{HA}-\mathrm{CDI}{ }^{[7]}$.

A large-scale retrospective case-control study of 8402 COVID-19 patients found a significant link between antibiotic use and CDI ${ }^{[8]}$. It showed that patients who developed CDI over the course of their COVID-19 admission were likely to have longer hospital stays and worse outcomes compared with patients who did not develop CDI. Most patients who developed CDI in the setting of COVID-19 were elderly (average age: 79 years) with multiple comorbidities (only $2.6 \%$ of patients who developed CDI had no comorbidities). The mortality rate was also significantly higher at $28 \%$ among COVID-19 patients with CDI compared with $5 \%$ among the general population with CDI ${ }^{[8]}$. This highlights that $\mathrm{CDI}$ should be ruled out if patients develop diarrhoea on antibiotic therapy.

$\mathrm{CDI}$ is a challenging disease with a recurrence rate of $15-20 \%$ and mortality rate of $5 \%{ }^{[9]}$. While there is a general paucity of data regarding CDI in COVID-19 patients, we found three case reports which make for interesting comparisons with our patient ${ }^{[10-12]}$. All of these cases, plus the nine subjects discussed by Sandhu et al., emerged in the setting of extensive use of broad-spectrum antibiotics leading to severe CDI, as illustrated in Table $1^{[13]}$.

\section{CONCLUSION}

Our case highlights the importance of judicious use of antibiotics in patients with COVID-19 infection. Therefore, we should continue to follow established guidelines of antimicrobial stewardship and remain vigilant for expected antimicrobial adverse effects. 


\begin{tabular}{|c|c|c|c|c|c|c|c|}
\hline Case & Age/gender & $\begin{array}{l}\text { Comorbid } \\
\text { conditions }\end{array}$ & $\begin{array}{l}\text { Presenting } \\
\text { complaint }\end{array}$ & $\begin{array}{l}\text { CDI onset } \\
\text { (days after } \\
\text { COVID-19 } \\
\text { diagnosis) }\end{array}$ & Complications & Management of CDI & Outcome \\
\hline $\begin{array}{l}\text { Ramalingam } \\
\text { et al. [10] }\end{array}$ & $40 / M$ & $\begin{array}{l}\text { Hypertension, } \\
\text { type Il diabetes } \\
\text { mellitus }\end{array}$ & $\begin{array}{l}\text { Abdominal pain, } \\
\text { shortness of } \\
\text { breath, diarrhoea, } \\
\text { altered mental } \\
\text { status }\end{array}$ & Day 1 & $\begin{array}{l}\text { Hyperammonaemia, } \\
\text { acute kidney injury }\end{array}$ & $\begin{array}{l}\text { Oral vancomycin failed, } \\
\text { then responded to oral } \\
\text { fidaxomicin }\end{array}$ & Alive \\
\hline $\begin{array}{l}\text { Rokkam et al. } \\
{[11]}\end{array}$ & $66 / F$ & $\begin{array}{l}\text { Fibromyalgia, } \\
\text { hypertension, } \\
\text { traumatic brain } \\
\text { injury, GERD, } \\
\text { constipation }\end{array}$ & $\begin{array}{l}\text { Watery diarrhoea } \\
\text { and altered mental } \\
\text { status, hypotension }\end{array}$ & Day 14 & $\begin{array}{l}\text { Acute kidney } \\
\text { injury, portal vein } \\
\text { thrombosis }\end{array}$ & Oral vancomycin & Alive \\
\hline $\begin{array}{l}\text { Páramo- } \\
\text { Zunzunegui } \\
\text { et al. [12] }\end{array}$ & $63 / F$ & NA & $\begin{array}{l}\text { Diarrhoea, } \\
\text { constipation, } \\
\text { abdominal pain }\end{array}$ & Day 40 & $\begin{array}{l}\text { Bilateral pulmonary } \\
\text { emboli, renal failure, } \\
\text { pancolitis with } \\
\text { perforation }\end{array}$ & $\begin{array}{l}\text { IV metronidazole and } \\
\text { intra-rectal vancomycin, } \\
\text { pancolectomy }\end{array}$ & Alive \\
\hline $\begin{array}{l}\text { Sandhu et al. } \\
{[13]}\end{array}$ & $\begin{array}{l}\text { Average } \\
75 / 7 \mathrm{~F} \text { and } \\
2 \mathrm{M}\end{array}$ & $\begin{array}{l}\text { Hypertension } \\
(n=8) ; \text { diabetes } \\
(n=5)\end{array}$ & $\begin{array}{l}\text { Cough, shortness } \\
\text { of breath, fever, } \\
\text { diarrhoea and } \\
\text { abdominal pain }\end{array}$ & $\begin{array}{l}\text { Day } 6 \\
\text { average }\end{array}$ & Unknown & $\begin{array}{l}\text { Oral vancomycin }(\mathrm{n}=6) \text {; } \\
\text { vancomycin and IV } \\
\text { metronidazole }(\mathrm{n}=1) ; \\
\text { no treatment }(\mathrm{n}=1) ; \\
\text { combination of oral } \\
\text { vancomycin, IV } \\
\text { metronidazole,rectal } \\
\text { vancomycin, fidaxomicin, } \\
\text { and faecal microbiota } \\
\text { transplantation }(n=1)\end{array}$ & $\begin{array}{l}\text { Alive }(n=5) ; \\
\text { Dead }(n=4)\end{array}$ \\
\hline
\end{tabular}

Table 1 All SARS-CoV-2 and Clostridium difficile co-infection cases reported to date

CDI, Clostridium difficile infection; COVID-19, novel coronavirus disease 2019; F, female; IV, intravenous; M, male; n, number/frequency; NA, not applicable. 


\section{REFERENCES}

1. Khanna S, Kraft CS. The interplay of SARS-CoV-2 and Clostridioides difficile infection. Future Microbiol 2021;16:439-443.

2. Stokes EK, Zambrano LD, Anderson KN, Marder EP, Raz KM, El Burai Felix S, et al. Coronavirus disease 2019 case surveillance - United States, January 22-May 30, 2020. MMWR Morb Mortal Wkly Rep 2020;69:759-765.

3. Tirlapur N, Puthucheary ZA, Cooper JA, Sanders J, Coen PG, Moonesinghe SR, et al. Diarrhoea in the critically ill is common, associated with poor outcome, and rarely due to Clostridium difficile. Sci Rep 2016;6:24691.

4. Bentivegna E, Alessio G, Spuntarelli V, Luciani M, Santino I, Simmaco M, et al. Impact of COVID-19 prevention measures on risk of health care-associated Clostridium difficile infection. Am J Infect Control 2021;49:640-642.

5. Rawson TM, Moore LSP, Zhu N, Ranganathan N, Skolimowska K, Gilchrist M, et al. Bacterial and fungal coinfection in individuals with coronavirus: a rapid review to support COVID-19 antimicrobial prescribing. Clin Infect Dis 2020;71:2459-2468

6. Zuo T, Zhang F, Lui GCY, Yeoh YK, Li AYL, Zhan H, et al. Alterations in gut microbiota of patients with COVID-19 during time of hospitalization. Gastroenterology 2020;159:944955.e8.

7. Huttner BD, Catho G, Pano-Pardo JR, Pulcini C, Schouten J. COVID-19: don't neglect antimicrobial stewardship principles! Clin Microbiol Infect 2020;26:808-810.

8. Granata G, Bartoloni A, Codeluppi M, Contadini I, Cristini F, Fantoni M, et al. The burden of Clostridioides difficile Infection during the COVID-19 pandemic: a retrospective case-control study in italian hospitals (CloVid). J Clin Med 2020;9:3855.

9. Guh AY, Mu Y, Winston LG, Johnston H, Olson D, Farley MM, et al. Burden of Clostridioides difficile infection and outcomes. N Engl J Med 2020;382:1320-1330.

10. Ramalingam S, Gunasekaran K, Arora H, Muruganandam M, Padmanabhan P. Clostridium difficile and noncirrhotic hyperammonnemia in a patient with COVID-19 infection. Cureus 2021;13:e14533.

11. Rokkam VRP, Kutti Sridharan G, Vegunta R, Vegunta R, Boregowda U, Mohan BP. Clostridium difficile and COVID-19: novel risk factors for acute portal vein thrombosis. Case Rep Vasc Med 2021;2021:8832638.

12. Páramo-Zunzunegui J, Ortega-Fernández I, Calvo-Espino P, Diego-Hernández C, Ariza-lbarra I, Otazu-Canals L, et al. Severe Clostridium difficile colitis as potential late complication associated with COVID-19. Ann R Coll Surg Engl 2020;102:e176-e179.

13. Sandhu A, Tillotson G, Polistico J, Salimnia H, Cranis M, Moshos J, et al. Clostridioides difficile in COVID-19 Patients, Detroit, Michigan, USA, March-April 2020. Emerg Infect Dis 2020;26:2272-2274. 